\title{
Linguistic Human Rights of Minorities and Language Policy: A Case Study of Balochi Language in Education in Lyari, Karachi, Pakistan
}

\author{
Shoaib A. Shah \\ MS student: shoaib.shah@usindh.edu.pk \\ English Language Development Center (ELDC) \\ Mehran University of Engineering and Technology (MUET), Jamshoro, Sindh, Pakistan \\ Dr. Ambreen Shahriar \\ Associate Professor: ambreen.shaikh@usindh.edu.pk \\ Institute of English Language and Literature, University of Sindh, Jamshoro, Pakistan \\ Dr. Habibullah Pathan \\ Associate Professor: habibullah.pathan@faculty.muet.edu.pk \\ English Language Development Center (ELDC) \\ Mehran University of Engineering and Technology (MUET), Jamshoro, Sindh, Pakistan
}

\begin{abstract}
Most of the neo-colonial nation-states in South America, Africa and Asia have historically remained multilingual. Particularly, subcontinent, being the part of Indus Civilization, successfully maintained the legacy of religious and cultural diversity. Pre-colonial lingo-cultural diversity in subcontinent was discouraged and displaced by new linguistic hierarchy during colonial times. In the milieu of WW-II and national liberation movements throughout the world, classical colonial structure was largely weakened at global level and paved the way for internal colonialism. Political leadership of newly formed multiethnic states principally preferred to govern their people as colonial subjects rather than free citizens. European model of 'one language, one culture and one state' has hitherto resulted in many ethno-linguistic movements in different neo-colonial states. Neo-colonial forms of knowledge, categories and instruments of oppression; particularly language policy; is still prevailing in such (in)dependent states where Pakistan is not an exception. Since 1947, language policy in Pakistan has been mainly shaped by and still continues to be overshadowed by its colonial past. This article critically investigates promise(s) and practice(s) of national language policy and the status of linguistic human rights of minorities in education in Lyari, Karachi, Pakistan. The data was collected from various (inter)national public policy documents/declarations along with semi-structured interviews from four different groups of participants i.e. academics, cultural activists, teachers and parents. Findings reveal two diametrically opposed orientations in terms of the use of mother tongue in classroom. School teachers stridently advocated assimilationist language ideology and viewed multilingualism in classroom as a problem to be solved, whereas, cultural activists and academics consider the same as a cultural resource to be properly utilized and the right of the child to be respected. Parents'views are also considered in order to explore the tension between the language of schooling and the language of early socialization of children at home. Moreover, Language Rights model is applied in order to explore (re)production of linguistic injustice through language policy in education.
\end{abstract}

Keywords: language policy, language rights, internal linguistic colonialism, Linguistic justice, Multilingualism Indigenous/minoritised languages in early education

DOI: $10.7176 /$ JLLL/83-06

Publication date: November $30^{\text {th }} 2021$

\section{Introduction}

Current research on medium of instruction (MoI) in multilingual countries recognizes plurilingual practices as proficiency and supports the use of local language(s) or mother tongue in classroom. In such countries critical investigation on language policy and planning or sociolinguistics stridently, advocates education in mother language (Hornberger, 2006; Mohanty, 2008; Cummins, 2009) and considers plurilingual repertoires as a resource to be properly utilized (Ruiz, 1984; Canagarajah \& Ashraf, 2013; Taylor, 2020). Another development, pertinent to the question of the importance of indigenous/minor languages, has been brought to the fore by (linguistic) human rights experts (May, 2011; Kymlicka \& Pfostl, 2014; Babaci-Wilhite, 2015; de Varennes \& Kuzborska, 2016; Skutnabb-Kangas \& Phillipson, 2017). Eco-linguists present yet another set of arguments for the maintenance and revitalization of indigenous/minor languages in the world. They argue that linguistic 
diversity is dialectically connected with the bio-diversity; hence, extinction of the one will inevitably affect the existence of the other. (Crystal, 2000, p.33; Nettle \& Romaine, 2000; Mufwene, 2004; Harrison, 2007; Ansaldo, 2009; Terralingua.org) This case study of Balochi language in primary schools in Lyari, Karachi, is inspired from the same scholarship and attempts to explore cognitive function and legal status of mother/other language(s) in education.

In British India, linguistic diversity/uniformity, Mir suggests, was consciously (re)structured for social division through colonial language policy (2010). This linguistic engineering associated different languages/scripts with different faiths i.e. Arabic/Urdu (written in Shahmukhi) with Islam, Sanskrit/Hindi (written in Devanagari) with Hinduism, Punjabi (written in Gurumukhi) with Sikhism (ibid) and generated many ethno-linguistic identities. Talbot states, language has acted as an important marker of identity and source of political mobilization in South Asia as is evidenced, for example, by the Telegu movement in the Indian state of Andhra Pradesh and the Dravidian movement and rise of the Dravida Munnetra Kazhagam in Tamil Nadu (1998, p.25). Pakistan continues the same socio-linguistic legacy and has hitherto observed several language movements including the one (Bengali) that eventually culminated in the dismembered of the country in 1971(Rahman, 1996; Ayres, 2009; Pinnock, 2009, p.19; Toor, 2011). Language policy (LP), Freeman postulates, works better if it includes the needs and wishes of a community, while a strictly vertical policy may result in resistance (2004).

Like many neo-colonial states, Pakistan is extraordinary for its lingo-cultural diversity that is as high as 0.826 , with 74 living languages (Eberhard et al., 2020). Rahman states there are six major and over 57 other languages in Pakistan (2009, p.03). Several additional estimations, i.e. 75 languages (Pinnock, 2009, p.50), 71 languages (Coleman, 2010), 77 languages (Ethnologue, 2014), further reflect the degree of linguistic diversity within country. Instead of celebrating linguistic diversity as a cultural recourse, a centralized 'control-oriented, top down language policy' (Siiner, 2014, p.7) has always been, overtly/covertly, put into practice. Nonstate/indigenous languages are looked down as voices from the Tower of Babel, whereas, dominant languages i.e. English, the former colonial language and Urdu, the sole national language, apart from (re)silencing these voices, are on the holy mission of 'modernization' (Phillipson, 1992 \& 2003) and 'Pakistanisation' (Haqqani, 2018) respectively. In Pakistan, generally, it is not English but Urdu that is posing serious threat to the cultural diversity in the country, as Rahman calls it 'Urdu imperialism' (2010, p.25). English, to greater extent, deals with the economical question. However, it is Urdu that is becoming the prime reason of 'discourse attrition'; that is 'deprived languages' end up surviving limitedly in educational, political and public situations (Crystal: 2000, p.21). In the course of the research following questions were explored.

\subsection{Statement of problem}

Present research explores LHRs of indigenous/minoritised languages in relation to language policy in education in primary schools in Lyari. The attempt conceptualizes construction of minorities as an ongoing process of peripheralization in relation to centre-periphery dynamics within nation-state. Several researchers have investigated MoI, language policy and minor languages in education in Pakistan. All these attempts have explored indigenous languages in fixed provincial boundaries and have seen language communities as bounded entities; therefore, Balochi is researched within Baluchistan's borders only. However, pre-partition indigenous languages and formation of new linguistic minorities in mega city like Karachi due to internal migration, is yet an unexplored terrain. This attempt brings study of periphery to the centre by considering Balochi as one of the many indigenous languages of Karachi. Moreover, investigation of language policy in education in relation to international law and linguistic justice in Lyari situates this attempt second to none.

\subsection{Research Questions}

This research attempts to address following questions:

1. How does hierarchization of languages in language policy in education affect Balochi children?

2. How and why indigenous/minor languages are peripheralized in primary schools?

3. How linguistic human rights of minorities are promised in international declarations, outlined in national language policy documents and practiced in primary schools in Lyari, Karachi, Pakistan?

\section{Literature Review}

\subsection{Hierarchization of languages at national and supranational level:}

The questions of linguistic rights and concerns about 'linguistic justice' (Mowbray, 2012; Piller, 2016), pertinent to the indigenous/minor languages, are not exclusive to Pakistan only. Such issues range from national to supranational bodies. On one hand side institutions like United Nation (UN) or European Union (EU) ardently, 
advocate linguistic diversity/equality in theory (Sallabank, 2011, p.283), but on other hand side in practice, overtly or covertly, hierarchical relation among languages is maintained. There are six (06); Chinese, Spanish, English, Russian, French and Arabic, official languages at UN but none of them, Ngugi argues, is of African origin (1993, p.56). Other unofficial languages are allowed in meetings but one is expected to provide an interpretation or written text of their speech in one of the official languages. Almost same vertical linguistic relations, with growing influence of English, are outlined by Phillipson in the context of EU (2003). Graddol (2000, p.13) expresses the identical ideas.

In Pakistan, since its inception in 1947, linguistic hierarchization and 'regimentation' of languages (Costa, 2018) is very similar to the one that is demonstrated in Figure: 02 . Ruling elite that was formed and trained by colonial master continues to govern different ethnicities/nationalities as their subjects. In many cases, immigrants' language/culture is threatened by the language of the majority in the state; however, in the history of Pakistan it has proved to be other way round. Unlike many countries, in Pakistan, the national language is not the language of the majority i.e. Bengali in United Pakistan, before 1971 was spoken by $54.6 \%$ population (Upreti, 2006, p.34) and Punjabi at present is spoken by $38.78 \%$ (Census, 2017; cited in Haidar, 2021, p.102). Instead, a less popular and the language of the immigrants named 'Urdu', mainly for geo-political/ideological concerns, was declared as the sole national language.

\subsection{Baloch as an indigenous language community in Lyari, Karachi:}

The 'indigenous people' are described by numerous terms i.e. Local, First Nation, Aboriginal and Native; however, there is no single definition that identifies who is an indigenous person. The most commonly cited explanation of the term was outlined by Jose R. Martinez Cobo as:

'.....those having a historical continuity with pre-invasion and pre-colonial societies that developed on their territories, consider themselves distinct from other sectors of the societies now prevailing in those territories, or parts of them. They form at present nondominant sectors of society and are determined to preserve, develop, and transmit to future generations their ancestral territories and their ethnic identity, as the basis of their continued existence as peoples, in accordance with their own cultural patterns, social institutions, and legal systems' (James et al., 2015, p.40).

Lyari as part of Karachi's original 'old city', Slimbach states, hosts the largest population of Baloch (1996, P.139), however, after Partition in 1947, demography of Karachi was categorically changed due to the influx of Urdu speaking immigrants from India. Partition, Pandey claims, initiated a process of 'nationalization' of disparate contexts, communities and locations into the idea of one nation. This process, he adds, lead to the coercion and domination of different ethnicities that were sidelined when the nascent nation's formation was being imagined (2004). Members of these ethnicities were to be assimilated into an obscure model of the 'ideal Pakistani'. The Baloch are, one of the many, who are excluded from the construction of the country they live in. Post Partition territorialized concept of identity, exclusively, associated Bloch of Karachi to the province of Balochistan. This notion has further diffused their relation with the city that their forebears had created. Conversely, Mohammad argues that Karachi, being the largest Baloch urban centre, has been extensively contributing in the development of Baloch literary movement, national consciousness and modern politics. This can be estimated, he adds, from thirteen Baloch elected members, out of twenty seven, in Sindh Provincial Assembly in 1970 (Mohammad, 2004, p.22).

2.3 Language policy in education and indigenous/minoritised languages: Language policies, Cardinal et al argues, are political; therefore, often have socio-political consequences. They can diffuse or reinforce conflict between language groups and can be the instruments of in|exclusion (2015). In multilingual contexts, language teaching and learning, in general, and the selection of language(s) as MoI, in particular, have never remained a neutral choice. Education authorities, in numerous cases, have disregarded advantages of multilingual and mother tongue based MoI policies; and have endorsed such polices that research evidence proposes are possibly inappropriate to educational process and achievements. MoI policies in multicultural contexts, Tollefson suggests, are usually part of political but educational agendas, as a result, any analysis of LP must consider all social factors that contribute in the formation and implementation of any specific MoI policies (2015).

In multi-ethnic states prioritisation of certain language(s) in LP or MoI; deeply reflect(s) the underlying socioeconomic tensions between ethnicities. LP like other state policies is profoundly intertwined with inter|national affairs. LP, Phillipson states, is markedly an essential component of social policy (2003). The processes of decentralisation and democratisation in the society, Siiner posits, are integral to the development of LP (2014). However, most of the neo-colonial multi-lingual states constitute such type of LP that contributes in linguistic homogenisation and cultural assimilation. Linguistic diversity, through nationalist agenda of schooling, is discouraged. Societal language(s) that often dominate minority languages (Schalley et al, 2020, p.328 ), is 
inculcated as the only legitimate form of linguistic expression; therefore, LP is viewed as a mechanism of power by critical theorists. They argue, such linguistic patterns of power are able to marginalize minority language and its users. LP in education that deliberately attempts the assimilation of indigenous people into the dominant national culture, James et al suggest, is the genocide of indigenous peoples' identities and cultures (2015). Such policy, Sallabank states, considers multilingualism as a problem, consequently, discourages minority languages and linguistic diversity and promotes national language(s) as an instrument for unification and nation-building (2013). These assumptions negatively affect language attitudes, choices and motivation of teachers, students and citizens. Educators, Shelley argues, should view different competences that students have in the languages in their linguistic repertoires as resources to be drawn on, not deficits (2020, p.208).

\section{Theoretical Framework:}

Violence, ideological, epistemic or corporal, in education has always brought debates about rights and justice to the fore. Since, this attempt advocates linguistic justice and questions legitimized language hierarchy in education, therefore; Linguistic Human Rights model (LHRs) is taken as theoretical lens and defined as under: Two related theoretical models of linguistic rights have gained wide currency, since last three decades in sociolinguistics literature: LHRs and Minority Language Rights (MLRs). Both models focus on the acceptance and recognition of the linguistic rights of minority language speakers. The LHRs model asserts that the right to language is a fundamental human right (Phillipson \& Skutnabb-Kangas, 1995). LHRs, Skutnabb-Kangas states, combine language rights with human rights. Such rights are 'so fundamental, that no state (or individual or group) is supposed to violate them' (2006, p. 273).

When studying language rights in Pakistan, it is very essential to examine how the negation of such rights has affected learning and active participation of children in class. Furthermore, denial of such basic rights has resulted in numerous language movements, inter-ethnic violence and even civil war that disintegrated the country in 1971. Ethnic conflicts can not merely be reduced to language only, however, Phillipson et al argue, in many cases, language related issues end in violence when they are coupled with the denial of political and economic rights (1995). Granting language rights to minorities lessens chances for violence and promotes harmony and tolerance.

\section{Methodology:}

This study is a qualitative collective case study. LHRs model is employed to analyze and interpret the data under investigation. Qualitative case studies often consider more than one data collecting tools, therefore; this research draws on semi-structured interviews and inter|national declarations/documents about language rights and language policy in education, as data collection instruments. The population of the study includes; four Baloch parents, four Baloch primary school teachers, four academics and four cultural activists. Samples were selected purposefully: parents and teachers on having close contact with children, whereas, academics and cultural activists on having rich information about the research problem. All these samples/spheres are dialectically connected with one another and reflect different stages in which indigenous languages are systematically minoritised

All groups of the participants mirror different but overlapping institutions of the state. At home MT (Balochi) is widely used, at school MT is used in break time or students speak in MT secretly in class particularly when teacher is writing on the board, at university there may or may not be a degree or certificate course in MT but in the highest institutions of the state like provincial assemblies, parliament, supreme and high courts MT is completely excluded from formal proceedings. Interviews were conducted in the languages in which participants were more comfortable and later translated into English. The analysis was structured on the basis of a six-phase process: familiarizing with data, generating initial codes, searching for theme reviewing themes, defining and naming themes and producing the report, proposed by Braun and Clarke (2006).

\section{Findings and Discussion}

5.1 LHRs and minoritised languages in education:

LHRs, Skutnabb-Kangas states, combine human rights with language rights. LHRs are those fundamental language rights that every person has by virtue of being a human. Such rights are basic and necessary for living a dignified life, therefore; so inalienable that no individual/group/state is allowed to violate them under any circumstances (2019). An unconditional right to MT medium multilingual education in state schools, she adds, is 
the most important LHR in education for the maintenance of indigenous/minority languages. Denial of LHRs in education makes subtractive education through the medium of dominant language(s) acceptable for minorities. Subtractive language learning establishes unstable diglossic situation where societal language is learned at the cost of the MT. This type of language learning eventually, results in the complete replacement of the MT. Mass media and educational systems, having assimilationist ideology, are the central institutions for cultural and linguistic genocide. A paradigm shift is needed, Tomasevski argues, otherwise schooling can be deadly (for the languages of minoritised communities). She insists on the implementation of a Rights-Based Approach in education that entails recognition and elimination of contrary educational practices in schools (2006). In international law, particularly, in UN Declaration on the Rights of Persons Belonging to National or Ethnic, Religious and Linguistic Minorities (1992) various measures are taken for the protection of minorities. Article 4 of the declaration states:

(I) States shall protect the existence and the national or ethnic, cultural, religious and linguistic identity of minorities within their respective territories, and shall encourage conditions for the promotion of that identity

(II) States shall adopt appropriate legislative and other measures to achieve those ends.

(III) States should take appropriate measures so that, wherever possible, persons belonging to minorities have adequate opportunities to learn their mother tongue or to have instruction in their mother tongue. (Bold added)

Clause 03, like many other legal instruments, defines language issues very loosely; consequently, such measures can be modified and may have alternatives. What is "appropriate", "possible" and "adequate" for ruling elite may not be the same for minoritised communities and vice versa. That is why May argues that language rights have been 'Cinderella' or a 'bastard stepchild' in the family of HRs. Such rights are unwittingly implemented, deliberately ignored, unwillingly accepted. Developments in international law, he adds, are at once both encouraging and disappointing (2011, p. 275). In many countries education is not conducted in local languages, therefore; such educational systems are de-contextualised and incapable of promoting intellectual and critical inquiry. HRs researchers strongly suggest that contextualised curriculum in local language(s) must be considered as a part of HRs in education (Skutnabb-Kangas, 2000; Tomasevski, 2006; Babaci-Wilhite, 2020).

\subsection{Indigenous languages, mother tongue and international law:}

Throughout the world indigenous people and their languages are in vulnerable condition. These people often cannot use their own languages, specifically, in formal contexts i.e. courts, education, media, parliament. Vulnerability of such 'people' and the relegation of their 'languages' to margins bilaterally influence each other and ultimately end in language shift. UNESCO (2019) reports suggest that $40 \%$ of the total estimated 6700 languages are seriously endangered. The majority of these are the languages of the indigenous people. In the milieu of the same UNESCO declared 2019 as the International Year of Indigenous Languages, where access to education 'in and about indigenous languages' is considered as central objective of the year (Jan.14, 2019). United Nations General Assembly (UNGA), in relation to UNESCO's declaration, has proclaimed 2022-32 as the International Decade of Indigenous Languages. The Decade will concentrate on development of the lives of the indigenous people and the promotion, preservation and revitalization of their languages that are dying unprecedentedly. Language loss, Carpenter et al argue, in many cases, has occurred due to diseases, genocide, slavery and displacement in the wake of colonialism. However, in contemporary world assimilatory policies of the nation-states have suppressed and resultantly, have proved to be more pernicious for indigenous languages than ever before. Such policies, they add, along with changing economical and social conditions, have contributed in the process of 'language shift' in which dominant language(s) are adopted by dominated (2020, p. 60).

Mother tongue, Skutnabb-Kangas states, encompasses many definitions like 'the language learned first' (origin), 'the language one identifies with and is known as its native speaker by others' (identity), 'the language one uses the most' (function) and 'the language one knows the best' (competence). One person, she adds, can have different MTs at the same time or can change MT several times in life with exception to the language of origin which will always remain as the language learned first (2010). Research suggests that mother tongue based multilingual education (MTB MLE) reduces drop out ration and enhances bi-literacy and participation of children in schools (Malone, 2018; Naviwala, 2019; Minha, 2020). International institutions; like UNESCO and UNICEF has always supported primary education in MT. UNESCO argues that it is very important to 'promote the use of MT in the early childhood education, early years of primary education and adult education; link personal development to the learners' cultural heritage and strengthen their self-confidence' (2000, p.28). 
Furthermore, UNESCO proposes that MTB MLE is beneficial to individual states and the world: Education can resiliently, be used to counter violent conflicts. The single and most vital skill that schools, in $21^{\text {st }}$ century, need to teach children is the skill of living peacefully with others and the skill for a thriving multicultural society. Awareness of diversity in its any form i.e. lingo-cultural, racial, ethnic or religious should be celebrated, respected and recognized but banished from the classroom (2010, p. 36). However, despite having consensus in international legal instruments on the use of MT in education and empirical evidences that advocate that learning occurs best in the language a child speaks fluently, there are around 221 million primary-aged students, Walter states, in the world, who are deprived of having schooling in their MT/ first language (2009). It is just $16 \%$ population in Pakistan that is having access to education in first language (ibid).

In Pakistan, Naviwala proposes, the only language that children speak and understand more is their MT like Hindko, Pashto, Sindhi, Punjabi or Siriaki but the language of the textbooks and instructions is either Urdu or English, as a result; children struggle in reading and comprehension in both of these languages (2019). MT is used, very rarely, in classroom but it is not the LoI or examination. In modern times, such type of linguistic exclusion when coupled with other politico-economical injustice has often been the reason of violent ethnic conflicts in many multinational states. UNESCO's Global Education Monitoring (GEM) Report of 2016 states that in multiethnic societies like Bangladesh, Pakistan, Turkey and Nepal, imposition of a dominant language(s) through school system has often been a main reason of grievance along with other socio-cultural inequalities.

\subsection{Constitution, linguistic minorities and language policy $v / s$ practice in schools in Pakistan:}

In various multiethnic nation-states, to some or greater extent; languages coexist uneasily. Whether covert or overt, a dominant (official/national/central) dominated (minoritised/peripheralized) relationship is usually observed amongst the speakers of major and minoritised languages. In many constitutions, outlining of language related legislation often manifests underlying tensions between different languages (speakers) within the same state. In terms of LP, there are two different approaches, Faingold suggests, in the formation of the constitution of a nation: "hands-off" and "hands-on". In former approach state does not draft any language provisions or promulgated any language as national or official. This approach 'leaves language alone'. However, in later in order to curtail intra-national linguistic issues one or more national or official languages are promulgated in the constitution (2004, p. 18). The Constitution of Pakistan of 1973 is primarily based on 'hands on' approach. There are mainly four Articles that address questions of education and language directly. They are mentioned as under:

Article: 25A. Right to education:

The State shall provide free and compulsory education to all children of the age of five to sixteen years in such manner as may be determined by law (Constitution of Pakistan, 2012, p.15. emphasis added)

In the wake of $18^{\text {th }}$ Amendment, Article 25A was introduced in the Constitution in 2010. Like many international legal instruments i.e. Dakar Framework of Action (2000), Article 25A protects educational rights of children but what would be the 'language' of the education is not clearly mentioned. Does it implicitly substantiate what Liaquat Ali Khan stated on Feb 23, 1948, in the first Constituent Assembly? Table 1 and figure 5 reveal very alarming numbers in this context and pose a serious question to what is determined by law is not reflecting the real state of the affairs. The Constitution guarantees free education for all children, yet there are millions, who are divested of their Constitutional right. In 2014 about 25.02 million, between 5-16 years, were out-of-school children (OOSC) in Pakistan says the report titled "25 Broken Promises" (Alif Ailaan, 2014), whereas in 2016 UNICEF estimated 22.8 million OOSC. This positions Pakistan as the world's $2^{\text {nd }}$ highest number of OOSC, according to the UNICEF. Many researchers, as mentioned in literature review, suggest that MTB MLE helps children to continue their education. The OOSC phenomenon cannot be reduced to the exclusion of MT only; there are socio-economical factors also. However, there are sufficient evidences that MTB MLE reduces drop-out ration and addresses 'capability deprivation' (Sen, 1985) appropriately.

Article: $28 . \quad$ Preservation of language, script and culture:

Subject to Article 251 any section of citizens having a distinct language, script or culture shall have the right to preserve and promote the same and subject to law, establish institutions for that purpose (ibid, 2012, p. 16, emphasis added).

In Article 28, State unlike Article 251, is attempting to be neutral. Article 28 protects the right of the preservation of distinct language, script and culture; however this all can only be stretched within the framework defied in Article 251, which gives Urdu privileged position. Thus, linguistic hierarchy as shown in figure 3; is in a way legalized and institutionalized. Furthermore, citizens are required to establish their own institutions for the protection and promotion of their language(s) but State. 
Article: $251 . \quad$ National language:

The National language of Pakistan is Urdu, and arrangements shall be made for its being used for official and other purposes within fifteen years from the commencing day.

Subject to clause (1), the English language may be used for official purposes until arrangements are made for its replacement by Urdu.

Without prejudice to the status of the National language, a Provincial Assembly may by law prescribe measures for the teaching, promotion and use of a provincial language in addition to the national language (ibid, 2012, p. 149, emphasis added).

The Constitution of 1973 was drafted just after two years of the fall of Dhaka in 1971. Language was one of the many reasons that caused dismemberment of United Pakistan, however; article 251(1) once again overlooks the ethno-linguistic diversity and declares Urdu as the only national language of the state. Declaration of single national language in multilingual state tacitly privileges that language and legalizes vertical relation with other languages within the same state. In this vertical relation in Pakistan, official and national languages are on the top, provincial at center and other indigenous languages at bottom. Clause (2) suggests that measures will be taken in fifteen years to replace English with Urdu. Contrariwise, almost five decades have passed but still such arrangements are non-existing. Linguist discrimination will continue to exist, even if Urdu replaces English. Linguistic justice cannot be achieved by just replacing one hegemonic language with another. In clause (3) status of provincial languages in relation to national language is explained. The phrase 'without prejudice', many linguists interpret, entails that without challenging or changing the position of national language, Provincial Assembly can take measures for the promotion of provincial language. However; such measures will not exclude the national language. Initial part of the clause (1) ignores linguistic diversity in the country, whereas; later part of clause 3 states about the promotion of provincial language only regardless of the fact that all provinces are also multilingual. This understanding of the provinces, as monolingual units, seems to be influenced by Belgian Linguistics, where; linguistic communities are conceptualized as monolithic entities on the bases of political demarcation

\subsection{Participants perspective on the use Mother tongue in early education:}

Parents, who are considered to be the world's largest language teaching force, are never involved in the process of the schooling. Their language and indigenous knowledge is dismissed, denigrated or at the very least delegitimised in classroom, therefore; child's pre-school accumulated lingo-cultural capital loses its value in school. Teachers being the representative of the centre view 'multilingual classroom' as a problem that should be solved by the implementation of the monolingual language policy of the state. They punish students differently if they find them speaking their MT, contrariwise; children were found speaking only their MT during break time. One teacher stated that 'children can play and fight in their own language but they must speak national language in classroom'. Moreover, he added that for the maintenance of discipline we follow states LP in school. Academics and cultural activists were found concerned with cognitive or educational benefits of schooling in MT. They interpreted LP multi-dimensionally and connected MoI issue to the politics of the ruling elite.

\section{Conclusion}

International law, theorists and sociolinguists suggest that the best language for early education is child's MT. Schooling in MT results in better and overall development of the child. Furthermore, MT substantiates in the learning of additional languages. Early education, Malone suggests, other than in most familiar language, specifically when child is struggling with poverty, poor learning conditions or hunger, is often too challenging for the learner to cope with. Conversely, MTB MLE, she adds, where other languages are gradually added into the linguistic repertoire of the children, have proved to be more successful (2018). Early schooling in less familiar language slows progress and increases anxiety in the children. Consequently, children get alienated and prefer to memorize their lessons which eventually damage their critical and creative orientations. Inculcation of such linguistic/learning practices has proved to be very unproductive. Multilingualism, like every country in the world, is an irrefutable reality in Pakistan. In fact it is multilingualism that has become a norm in the world. All languages must be respected and taken as a cultural resource. Governments instead of being just tolerant should actively intervene in the promotion of multilingualism. Languages should be used as bridges instead of banks. A bridge connects people; whereas, banks confine the flow in a determined way. 


\section{References}

Alif Ailaan. (2014). 25 Million Broken Promises: The Crisis of Pakistan's Out-of-School Children. Islamabad: Alif Ailaan. $\mathrm{x}+70 \mathrm{pp}$.

Ansaldo, U. (2009). Contact Languages: Ecology and Evolution in Asia: Cambridge: Cambridge University Press

Ayres, A. (2009). Speaking like a state: Language and nationalism in Pakistan. Cambridge UK: Cambridge University Press

Babaci-Wilhite, Zehlia. (2015). Language, Development Aid and Human Rights in Education: Curriculum Policies in Africa and Asia: Palgrave Macmillan UK

Babaci-Wilhite, Zehlia. (2020). Integral Education: Language and Human Rights in STEAM. In Learning Critical Thinking Skills Beyond 21st Century For Multidisciplinary Courses: A Human Right Perspective in Education. Bassim Hamadeh, CEO and Publisher

Canagarajah, S., \& Ashraf, H. (2013). Multilingualism and education in South Asia: Resolving policy/practice dilemmas. In Annual Review of Applied Linguistics, 33, 258-285.

Cardinal, L., \& Sonntag, Selma K. (2015). Introduction: State Traditions and Language Regimes: Conceptualizing Language Policy Choices. In Cardinal, L., \& Sonntag, Selma K (eds). State Traditions and Language Regimes. Canada. McGill-Queen's University Press

Carpenter, K., \& Tsykarev, A. (2020). (Indigenous) Language as a Human Right. In UCLA Journal of International Law and Foreign Affairs, Vol. 24, No. 49, 2020, U of Colorado Law Legal Studies Research Paper No. 20-45, Available at SSRN: https://ssrn.com/abstract=3649091

Coleman, H. (2010). Teaching and learning in Pakistan: The role of language in education. Islamabad Pakistan: The British Council

Costa, J. (2018). Introduction: Regimes of language and the social, hierarchized organization of ideologies. Language \& Communication. 66 (2019)1-5. doi.org/10.1016/j.langcom.2018.10.002

Crystal, D. (2000). Language Death. Cambridge; New York, NY: Cambridge University Press.

Cummins, J. (2009). Fundamental Psychological and Sociological Principles Underlying Educational Success for Linguistic Minority Students. In T. Skutnabb-Kangas, R. Phillipson, A.K. Mohanty, \& M. Panda (Eds.), Social justice through multilingual education (pp. 19-35). Bristol, England: Multilingual Matters

de Varennes, F., \& Kuzborska, E. (2016). Language, Rights and Opportunities: The Role of Language in the Inclusion and Exclusion of Indigenous Peoples. In International Journal on Minority and Group Rights. 23 (2016) 281-305. DOI. 10.1163/15718115-02303004 Retrieved July 30, 2021 from https://pk1lib.org/?signAll=1\&ts=1011

Eberhard, D. M., Simons, G. F., \& Fennig, C. D. (eds.). (2020). Ethnologue: Languages of the world. 23.

SIL International. Online version: http://www.ethnologue.com

Faingold, E. D. (2004). Language rights and language justice in the constitutions of the world. In Language Problems and Language Planning, 28(1), 11-24. Retrieved August 04, 2021 fromhttps://booksc.org/book/55531005/bda058. DOI: 10.1075/lplp.28.1.03fai

Freeman, R. (2004). Building on Community Bilingualism. Philadelphia, PA: Caslon.

Graddol, D. (2000). The Future of English. The British Council

Haidar, S., Wali, T., Tahir, T., \& Parveen, M. (2021). I am not Punjabi my Parents are: Degradation of the Language of Dominant Majority. In Acta Linguistica Asiatica, 11(2), 2021. DOI: 10.4312/ala.11.2.101-127

Haqqani, H. (2018, February 21). We are seeing a Pakistanisation of India [Video file] Retrieved from https://www.youtube.com/watch?v=gSv6GObndHk

Harrison, K. D. (2007). When Languages Die: The extinction of the world's languages and the erosion of human knowledge. New York ; Oxford: Oxford University Press

Hornberger, N. H. (2006). Policy, possibility and paradox: Indigenous multilingualism and education in Peru and Bolivia. In F. Genesee \& J. Cenoz (Eds.), Beyond bilingualism: Multilingualism and multilingual education (pp. 206-242). Cleveland: Multilingual Matters.

James, W. J., Liu, J., \& Lee, Che-Wei. (2015). Policy Debates and Indigenous Education: The Trialectic of 
Language, Culture and Identity. In Jacob, W. Cheng, Sh. \& Porter, M (Eds.), Indigenous Education: Language Culture and Identity. London, England: Springer.

Kymlicka, W \& Pfostl, E. (2014). Introduction. In Kymlicka, W \& Pfostl, E. (Eds.), Multiculturalism and Minority Rights in the Arab World: London: OUP

Malone, S. (2018). MTB MLE RESOURCE KIT: Including the Excluded: Promoting Multilingual Education: Bangkok. UNESCO

May, S. (2011). Language Policy. In Grenfell, M. (Ed). Bourdieu, Language and Linguistics. Continuum

May, S. (2011). Language Rights: The "Cinderella" Human Right. In Journal of Human Rights, (10) 265-289 DOI: $10.1080 / 14754835.2011 .596073$

Minha, K. (2020). Finding Identity, Equity, and Economic Strength by Teaching in Languages Children Understand: Mother tongue based multilingual education designed for schools in Pakistan: Karachi. The Citizens Foundation (TCF)

Mir, F. (2010). The Social Space of Language: Vernacular Culture in British Colonial Punjab. Berkeley University of California Press

Mohammad, T. Breseeg. (2004). Balochistan Nationalism: Its Origin and Development. Karachi: Royal Book Company

Mohanty, A. (2008). Perpetuating inequality: Language disadvantage and capability deprivation of tribal mother tongue speakers in India. In W. Harbert (Ed.), Language and Poverty (pp. 102-124). Cleveland: Multilingual Matters.

Mowbray, J. (2012). Linguistic Justice: International Law and Language Policy. Oxford: OUP

Mufwene, S. (2004). The Ecology of Language Evolution: Cambridge: Cambridge University Press

Naviwala, N. (2019). Why Can’t Pakistani Children Read? The Inside Story of Education Reform Efforts Gone Wrong. Washington, Wilson Center Asia Program. www.wilsoncenter.org

Nettle, D., \& Romaine, S. (2000). Vanishing voices: The extinction of the world's languages. Oxford: OUP

Ngugi, W. Thiongo. (1993). Moving the Centre: The Struggle for Cultural Freedom: London: James Currey

Pandey, G. (2004). Remembering Partition: Violence, Nationalism and History in India. Cambridge: Cambridge University Press

Phillipson, R. (1992). Linguistic Imperialism. Hong Kong. Oxford University Press

Phillipson, R. (2003). English-Only Europe? Challenging Language Policy. London: Routledge

Phillipson, R., \& Skutnabb-Kangas, T. (1995). Linguistic human rights, past and present. In T. Skutnabb-Kangas \& R. Phillipson (Eds.), Linguistic human rights: Overcoming linguistic discrimination (pp. 71-110). Berlin: Mouton de Gruyter.

Piller, I. (2016). Linguistic Diversity in Education: An Introduction to Applied Sociolinguistics. London: Oxford University Press

Pinnock, H. (2009). Language and education: the missing link. How the language used in schools threatens the achievement of Education For All. Retrieved on July 30, 2021 from www.savethechildren.org.uk

Rahman, T. (1996). Language and Politics in Pakistan. Karachi; Oxford: Oxford University Press.

Rahman, T. (2009). Language Policy, Language Death and Vitality in Pakistan. In Mansoor, S., Sikandar, A., Hussain, N. \& Ahsan, N. (Eds), Emerging Issues in TEFL: Challenges for Asia (pp. 03-30). Karachi: Oxford University Press

Rahman, T. (2010). Language Policy, Identity and Religion: Aspects of the Civilization of the Muslims of Pakistan and North India: Islamabad. National Institute of Pakistan Studies. Quaid-i-Azam University Islamabad

Ruiz, R. (1984). Orientations in language planning. NABE Journal, 8(2), 15-34.

Sallabank, J. (2012). Language Policy for Endangered Languages. In Austin. P \& Sallabank, J. (Eds), The Cambridge Handbook of Endangered Languages: New York: Cambridge University Press

Sallabank, J. (2013). Attitudes to Endangered Languages: Identities and Policies. Cambridge: Cambridge University Press

Schalley, A. C. \& S. Eisenchlas (eds.). 2020. Handbook of Home Language Maintenance and Development. 
Social and Affective Factors. Moutonde Gruyter

Sen, A. (1985). Commodities and Capabilities. Amsterdam: North Holland.

Siiner, M. (2014). Decentralisation and language policy: local municipalities' role in language education policies. Insights from Denmark and Estonia. In Journal of Multilingual and Multicultural Development. http://dx.doi.org/10.1080/01434632.2014.889143

Slimbach, R. (1996). Ethnic Binds and Pedagogies of Resistance: Baloch Nationalism and Education Innovation in Karachi. In Titus, P. (Ed), Marginality and Modernity: Ethnicity and Change in Post-Colonial Balochistan. Karachi: Oxford University Press

Skutnabb-Kangas, T. (2006). Language Policy and Linguistic Human Rights. In T. Ricento (Ed.), An Introduction to Language Policy: Theory and method (pp. 273-291). Malden, Mass. Oxford: Blackwell

Skutnabb-Kangas, T \& Dunbar, R. (2010). Indigenous Children's Education as Linguistic Genocide and a Crime Against Humanity? A Global View. In Varsi, O. Magne (ed). Gáldu Cála. In Journal of Indigenous Peoples Rights No. $1 / 2010$

Skutnabb-Kangas, T. \& Phillipson, R. (2017). Language Rights. London/New York: Routledge

Taylor, K. Shelley. (2020). Multilingualism. In Schmitt, N \& Rodgers, M (Eds.). An Introduction to Applied Linguistics. New York: Routledge

The Constitution of the Islamic Republic of Pakistan (28 Feb, 2012). Retrieved on 10.10.2021 from http://www.na.gov.pk/uploads/documents/1333523681_951.pdf

Tollefson, J. W. (2015). Language policy-making in multilingual education: mass media and the framing of medium of instruction. In Current Issues in Language Planning, 16:1-2,132-148, DOI:10.1080/14664208.2014.947018

Tomasevski, K. (2006). Human Rights Obligation in Education: The 4-A Scheme. Enfield Publishing \& Distribution Company

Toor, S. (2011). The State of Islam: Culture and cold War Politics in Pakistan. Karachi. OUP

UNESCO. (2000). The Dakar framework for action. Education for all: Meeting our collective commitments. Adopted by the World Education Forum. Dakar, Senegal, 26-28 April 2000. http://unesdoc.unesco.org/images/0012/001211/121147e.pdf[Accessed 08 0ctober, 2021]

UNESCO. (2010). Summary. Education for All Global Monitoring Report. Paris. UNESCO. http://unesdoc.unesco.org/images/0019/001911/191186e.pdf [Accessed 03 0ctober, 2021]

UNESCO. (2016). Peace: Building sustainable peace and global citizenship through education. UNESCO Global Education Monitoring Report https://en.unesco.org/gem-report/report/2016/education-people-and-planetcreating-sustainable-futures-all [Accessed 13 0ctober, 2021]

UNESCO. (2019). Action plan for organizing the 2019 International Year of Indigenous Languages. Permanent Forum on Indigenous Issues No. E/C.19/2018/8. Retrieved on 30.09.2021 from https://en.iyil2019.org/wpcontent/uploads/2018/09/N1804802.pdf]

UNICEF. (2016). Education: Giving every child the right to education. Retrieved on October 10, 2021 from https://www.unicef.org/pakistan/education

Upreti, S. (2006). Growth of Linguistic Nationalism. In Salim, A. (Ed.). It is my Mother's Face. Lahore:Sanjh Publications Pakistan.

Walter, S. (2009) Language as a variable in primary education. Arlington, TX: SIL International 